\title{
2-Monokloropropandiol (2-MCPD)'nin Sitotoksik Etkilerinin Fare TM3 Leydig ve TM4 Sertoli Hücreleri Üzerinde in vitro Değerlendirilmesi
}

\author{
Evaluation of Cytotoxic Effects of 2-Monochloropropanediol (2-MCPD) on Mouse TM3 Leydig \\ and TM4 Sertoli Cells in vitro
}

\author{
Can Özgür Yalçın ${ }^{1}$, Sezen Yılmaz Sarıaltın², Mahmoud Abudayyak ${ }^{3}$, Engin Yenilmez ${ }^{4}$
}

Geliş tarihi/Received: 17.12.2019 • Kabul tarihi/Accepted: 24.06.2020

\section{ÖZET}

Amaç: 2-monokloropropandiol (2-MCPD), 3-monokloropropandiol (3-MCPD) ve esterleri ile glisidil yağ asidi esteri (GE), gıda veya gıda işlem kaynaklı kontaminantlar olarak adlandırılmaktadır. Bu gıda kontaminantlarının başta palmiye yağı olmak üzere bitkisel yağlar, margarinler, pasta ve kek gibi işlem görmüş gıdalarda ve bebek mamalarında tespit edilmesi, güvenlikleri konusundaki ilgiyi arttırmıştır. Avrupa Gıda Güvenliği Otoritesi'nin (European Food Safety Authority, EFSA) Mayıs 2016 yılında yayınlamış olduğu bilimsel görüşe göre bitkisel yağ ve işlenmiş gıdalarda bulunan GE, 3-MCPD, 2-MCPD ve bunların yağ asidi esterlerinin insan sağlığı için zararlı olduğu raporlanmıştır. Ancak 2-MCPD toksisitesi hakkında yeterli veri olmadığı için tam bir değerlendirme yapılamamıştır. Bu amaçla 2-MCPD’nin, TM3 Leydig ve TM4 Sertoli hücre hatları üzerinde in vitro sitotoksik, apoptotik etkileri ve deoksiribonükleik asit (DNA) hasarı yapma potansiyeli değerlendirilmiştir.

Gereç ve Yöntem: Hücre canlılığı, 3-(4,5-dimetiltiyazol-2-il)-2,5-difeniltetrazolyum bromid (MTT) ve nötral kırmızısı alım (NRU) yöntemleri ile değerlendirilmiştir. Akış sitometrisi ile hücre ölüm tipinin belirlenmesinde aneksin V-FITC/PI ikili boyama kiti kullanılmıştır. Genotoksisite değerlendirmesinde komet yöntemi uygulanmıştır.

Bulgular: Hücre canlılık yöntemleri sonucu 2-MCPD’nin test edilen konsantrasyonlarda 1000 MM’a kadar sitotoksik olmadığı tespit edilmiştir. Aynı zamanda 2-MCPD’nin, sub-toksik konsantrasyonlarda (1-1000 $\mu \mathrm{M})$ her iki hücre hattında da (TM3 Leydig ve TM4 Sertoli hücreleri) DNA hasarını indüklemediği bulunmuştur.

Sonuç: 2-MCPD, her ne kadar test edilen konsantrasyonlarda (1-1000 $\mu \mathrm{M})$ sitotoksik ve apoptotik etki göstermese de daha yüksek konsantrasyonlarda hücre ölümüne ve DNA hasarına neden olabilir. Ancak bu yüksek konsantrasyonlar günlük maruziyet dozlarından çok uzaktır.

Anahtar kelimeler: 2-MCPD, TM3 Leydig hücre hattı, TM4 Sertoli hücre hatt, apoptozis

\begin{abstract}
Aim: 2-Monochloropropanediol (2-MCPD), 3-monochloropropanediol (3-MCPD), their esters and glycidyl fatty acid esters (GE) are important food contaminants originating mainly during food processing. Recently, the detection of these contaminants in different foods and vegetable oils, especially in palm oil, margarines, and processed foods such as pastries and cakes and in baby foods raises concerns about their safety. According to the European Food Safety Authority (EFSA) scientific report

\footnotetext{
1. İletişim/Correspondence: Karadeniz Teknik Üniversitesi, Eczacllık Fakültesi, Trabzon, Türkiye

2. Ankara Üniversitesi, Ankara, Türkiye - 다 https://orcid.org/0000-0002-8387-4146
}

E-posta: canozguryalcin@ktu.edu.tr • 이 https://orcid.org/0000-0003-4032-3229

3. Karadeniz Teknik Üniversitesi, Trabzon, Türkiye - (i) https://orcid.org/0000-0003-2286-4777

4. Karadeniz Teknik Üniversitesi, Trabzon, Türkiye - (1) https://orcid.org/0000-0002-0755-4394
\end{abstract}


published in May 2016, foods and vegetable oil contaminated with 3-MCPD, 2-MCPD and their fatty acid esters and GE were reported as harmful to human health. However, limited data on 2-MCPD toxicity preclude a complete assessment of its toxicity. For this reason, the cytotoxic, apoptotic effects and deoxyribonucleic acid (DNA) damage potential of 2-MCPD were evaluated on TM3 Leydig and TM4 Sertoli cells.

Material and method: The cell viability was evaluated by 3-(4,5-dimethylthiazol-2-yl)-2,5-diphenyltetrazolium bromide (MTT) and neutral red uptake (NRU) assays. Annexin V-FITC/PI double staining kit was used to indicate the type of cell death by flow cytometry. The alkaline comet assay was used to estimate the genotoxic effect.

Results: The cell viability assays showed that 2-MCPD was not cytotoxic within the tested concentrations up to $1000 \mu \mathrm{M}$ on both cell lines. These sub-toxic concentrations of 2-MCPD (1-1000 $\mu \mathrm{M})$ also did not induce DNA damage both on TM3 Leydig and TM4 Sertoli cells.

Conclusion: Although results demonstrate that tested concentrations of 2-MCPD (1-1000 $\mu \mathrm{M})$ were neither cytotoxic nor apoptotic but may cause cell death and DNA damage at higher concentrations. On the other hand, those high concentrations are far from the daily exposure doses.

Keywords: 2-MCPD, TM3 Leydig cell line, TM4 Sertoli cell line, apoptosis

\section{INTRODUCTION}

2-monochloropropanediol

3-monochloropropanediol

(3-MCPD), and their

fatty acid esters and glycidyl fatty acid esters (GE) are contaminants found in processed foods and vegetable oils. These substances mainly occur during the refining process where the raw oils were boiled at high temperatures, above $200{ }^{\circ} \mathrm{C}$, to remove the natural aromas (1). In 2016, these three contaminants were assessed by European Food Safety Authority (EFSA), in terms of their impact on public health. Glycidol, the main compound of GE, was reported to be genotoxic and carcinogenic (2,3), while 3-MCPD, another contaminant, was documented to damage kidneys and male reproductive organs (4-6). 2-MCPD which is an isomer of 3-MCPD occurs in lower levels than GE and 3-MCPD in refined vegetable oils (7). Thus, toxicologists have focused on 3-MCPD for numerous years and 2-MCPD has gained scientific attention much more lately.
Data on the effects of 2-MCPD on target organs are limited. Studies on the repeated-dose oral toxicity studies have reported that striated muscle and myocardium were the main organs/tissues affected by $2-\mathrm{MCPD}$, followed by kidneys. Although the reproductive toxicity of 3-MCPD has been summarized by the EFSA, there are no studies evaluating the effects of 2-MCPD on the reproductive system (2). Therefore, in the present study, we evaluated the in vitro toxic effect of 2-MCPD on mouse TM3 Leydig and TM4 Sertoli cells which represent the main male reproductive system cells. First, the cells were treated with a wide concentration range of 2-MCPD (1-1000 $\mu \mathrm{M})$ to determine possible cytotoxic effect by 3-(4,5-dimethylthiazol-2-yl)-2,5-diphenyltetrazolium bromide (MTT) and neutral red uptake (NRU) assays. Later, cell viability results and the cell death pathway were confirmed by flow cytometry assay using Annexin V-FITC/PI dyes. Finally, non-cytotoxic concentrations of 2-MCPD (1, 10, 100 and $1000 \mu \mathrm{M})$ were chosen for testing its genotoxic potential. 


\section{MATERIALS AND METHODS}

\section{Cell Culture}

The mouse TM3 Leydig and TM4 Sertoli were obtained from American Type Culture Collection (ATCC, Manassas, VA, USA). Cell lines were grown in DMEM/Ham's F12 medium (ATCC, Manassas, VA, USA) supplemented with 5\% horse serum (ATCC, Manassas, USA), $2.5 \%$ fetal bovine serum (ATCC, Manassas, VA, USA), 1\% penicillin (100 U/mL) and streptomycin (100 $\mu \mathrm{g} / \mathrm{mL}$ ) (Wisent, St. Bruno, QC, Canada). Both cells were cultured at $37^{\circ} \mathrm{C}$ with $5 \% \mathrm{CO} 2$ in an incubator. At 90\% confluence cells were treated by Tyripsin-EDTA (Wisent, St. Bruno, QC, Canada) for passage processes or sub-cultured into $25 \mathrm{~cm}^{2}$ flasks, 6 or 96 well plates according to the assay. The passage number of both TM3 and TM4 cells were 2 to 10 .

\section{Cytotoxicity Assay}

TM3 Leydig and TM4 Sertoli cells were incubated in 96-well plates in quantities of 5x103/well for $24 \mathrm{~h}$. 2-MCPD (Toronto Research Chemicals, North York, ON, Canada) was dissolved in dimethyl sulfoxide (DMSO) (Sigma-Aldrich, St. Louis, MO, USA). At the end of incubation, the culture medium was replaced with exposure medium including different concentrations of 2-MCPD $(1,10,100$, and $1000 \mu \mathrm{M})$, and incubated for another $24 \mathrm{~h}$. After the exposure period, the medium was removed for MTT assay and $100 \mu \mathrm{L}$ fresh serumfree medium containing $0.5 \mathrm{mg} / \mathrm{mL}$ MTT (Serva, Germany) was added to each well (8). For NRU assay, fresh serum-free medium containing $50 \mu \mathrm{g} / \mathrm{mL}$ NR (Sigma-Aldrich, St. Louis, MO, USA) was added to each well (9). Cells were incubated at $37^{\circ} \mathrm{C}$ for $3 \mathrm{~h}$ more. MTT and NR dye-containing medium was gently removed. In MTT plates, the formazan crystals were dissolved in $150 \mu \mathrm{L}$ DMSO, and the plates were shaken for 10 min at room temperature. In NRU plates, wells were washed twice with phosphate buffered saline (PBS) and $150 \mu \mathrm{L}$ glacial acetic acid/water/ethanol (1:49:50, $\mathrm{v} / \mathrm{v} / \mathrm{v}$ ) were added to each well. The absorbances were measured at $490 \mathrm{~nm}$ and $540 \mathrm{~nm}$ by using a microplate reader (Thermoscientific, Waltham, MA, USA) for MTT and NRU, respectively.

\section{Apoptosis Assay}

For the quantitative evaluation of apoptosis, the cells were seeded on 6 well plates in quantities of $2 \times 10^{5} /$ well for $24 \mathrm{~h}$. The cells were then treated by 10 and $1000 \mu \mathrm{M} 2-\mathrm{MCPD}$ for $24 \mathrm{~h}$. After that, TM3 cells were trypsinized and washed with cold PBS. The apoptosis was detected using an Annexin V-FITC/PI kit (cat. no. 556570; BD Pharmingen, San Jose, CA, USA) according to the manufacturers' protocol. Briefly, cells were suspended in $500 \mu \mathrm{L}$ binding buffer and $5 \mu \mathrm{L}$ Annexin V-FITC, and $5 \mu \mathrm{L}$ PI were added to this suspension. Then, cells were incubated in dark at room temperature for $15 \mathrm{~min}$. From each sample, $1.5 \times 10^{4}$ cells were analysed within $1 \mathrm{~h}$, using a flow cytometry (Accuri C6, BD Biosciences, San Jose, CA, USA).

\section{Genotoxicity Assay}

The alkaline comet assay was based on the standard method with minor modifications (10). TM3 Leydig and TM4 Sertoli cells were seeded in 6 well plates in quantities of $2 \times 10^{5} /$ well for $24 \mathrm{~h}$. Cells were then treated by 10 and $1000 \mu \mathrm{M} 2-\mathrm{MCPD}$ for $24 \mathrm{~h}$. After treatment, TM3 cells were detached with TrypsinEDTA, and were collected in separate $15 \mathrm{~mL}$ centrifuge tubes. The positive control group cells were treated by $\mathrm{H}_{2} \mathrm{O}_{2}$ (Tekkim Kimya San., Turkey) at $100 \mu \mathrm{M}$ for $1 \mathrm{~h}$ at $37^{\circ} \mathrm{C}$. The unexposed cells were accepted as negative control group. For all groups, the cells suspended in PBS were expected to be $5 \times 10^{4}$ cell $/ 100 \mu \mathrm{L}$. The cells were gently mixed with $100 \mu \mathrm{L}$ of low melting agar (LMA) (0.5\%) (HiMedia, Marc, Mumbai, India) and immediately pipetted onto the NMA (1\%) (HiMedia, Marc, Mumbai, India) pre-coated slides. Thereafter, the slides were covered by coverslip and put on an ice-pack for a couple of times for solidification. After 
removal of the coverslip, the slides were placed on a cold lysis solution (2.5 M NaCl, $100 \mathrm{mM} \mathrm{Na}_{2}$ EDTA, $10 \mathrm{mM}$ Tris, and $1 \%$ sodium sarcosinate at $\mathrm{pH}=10$ ) containing freshly added 1\% Triton-X 100 (Sigma-Aldrich, St. Louis, MO, USA), and 10\% DMSO for at least $1 \mathrm{~h}$ at $4{ }^{\circ} \mathrm{C}$. The lysis solution was removed and the slides were washed with the electrophoresis buffer. Then, the slides were placed on a horizontal electrophoresis tank filled with freshly prepared electrophoresis solution ( $1 \mathrm{mM} \mathrm{Na}{ }_{2}$ EDTA and $300 \mathrm{mM} \mathrm{NaOH}, \mathrm{pH}=13$ ). The slides were proceeded to alkaline denaturation and electrophoresis (20 V, $350 \mathrm{~mA}$ ) during $20 \mathrm{~min}$. Afterwards, the slides were washed with PBS and neutralized with Tris buffer (0.4 M Tris, $\mathrm{pH}=7.5)$ for $15 \mathrm{~min}$ at room temperature. The slides were fixed with 50\%, 75\% and $90 \%$ ethanol, respectively, before stained with ethidium bromide (EtBr) (Sigma-Aldrich, St. Louis, MO, USA). On the day of analysis, $100 \mu \mathrm{L}$ of EtBr ( $2 \mu \mathrm{g} / \mathrm{mL}$ in water) was added on each slide and covered with a coverslip. The slides were examined on a fluorescence microscope (Eclipse E800, Nikon, Japan) and images were analysed with a software (TriTek Corp, Sumerduck, VA, USA). Hundred cells on each slide randomly selected and analysed. DNA tail intensity (\%) was used for expressing the DNA damage.

\section{Statistical Analysis}

All assays were done in triplicates and repeated in different three days (total repetition $3 \times 3=9$ ). Data was expressed as mean \pm standard deviation (SD). The analysis of variance (ANOVA) and post-hoc Tukey tests were performed using GraphPad Prism version 6.0 (GraphPad Software Inc., La Jolla, CA, USA). A p-value less than $0.05(p<0.05)$ was considered to represent statistically significant results.

\section{RESULTS}

\section{Cytotoxicity Assays}

2-MCPD did not exhibit cytotoxic effect in TM3 Leydig and TM4 Sertoli cells up to $1000 \mu \mathrm{M}$. The viability of cells was more than $95 \%$ in all tested concentration groups both MTT and NRU assays (Figure 1).

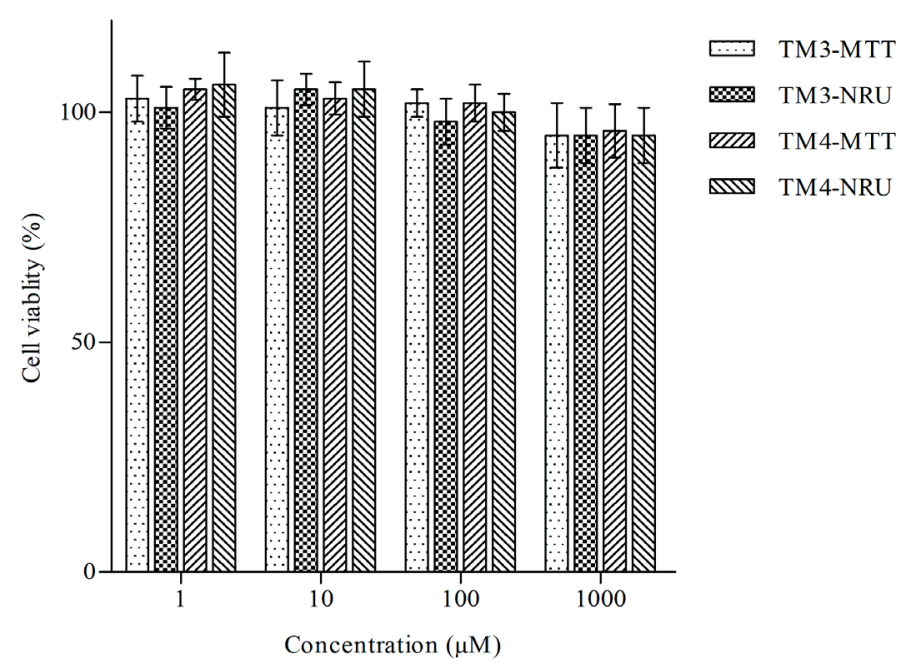

Figure 1. Results of 3-(4,5-dimethylthiazol-2-yl)-2,5diphenyltetrazolium bromide (MTT) and neutral red uptake (NRU) assays showed the cytotoxic effect of 2-MCPD in TM3 Leydig cells and TM4 Sertoli cells $(N=3)$. The cells were treated with different concentrations $(1-1000 \mu \mathrm{M})$ of 2-MCPD for $24 \mathrm{~h}$. Results are given as median of cell viability (\%). The error bar represents \pm standard error.

\section{Apoptosis Assay}

The percentage of TM3 Leydig and TM4 Sertoli cells undergoing early apoptosis was not significantly changed by 10 and $1000 \mu \mathrm{M}$ of 2-MCPD exposure (Figure 2). 


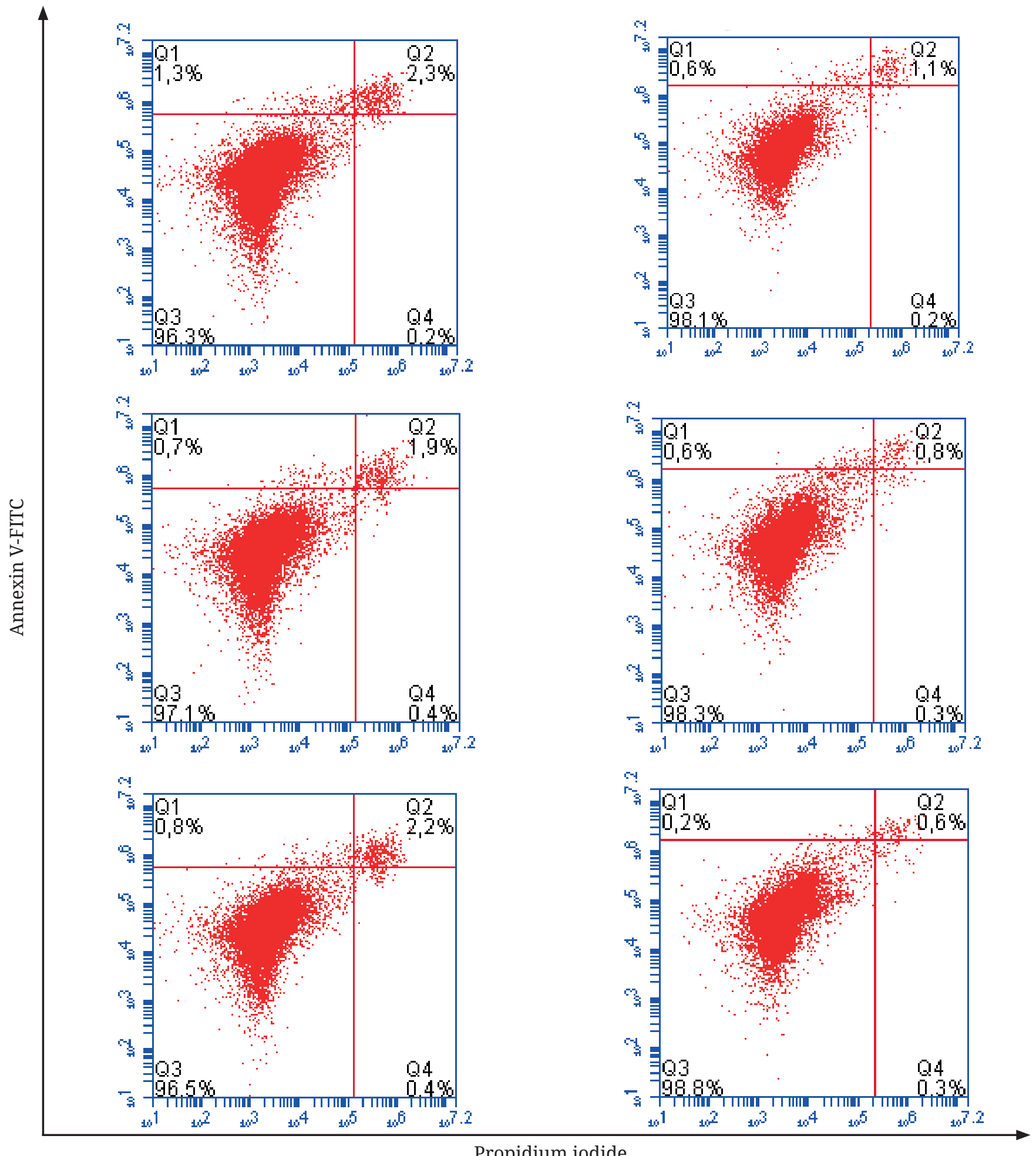

Propidium iodide

Figure 2. Flow cytometry analysis of apoptotic/necrotic TM3 Leydig and TM4 Sertoli cells $(N=3)$. (a) Negative control group of TM3 cells. (b) TM3 cells treated with $10 \mu \mathrm{M}$ and (c) $1000 \mu \mathrm{M}$ of 2-MCPD. (d) Negative control group of TM4 cells. (e) TM4 cells treated with $10 \mu \mathrm{M}$ and (f) $1000 \mu \mathrm{M}$ of 2-MCPD. 


\section{Genotoxicity Assay}

The results of the alkaline comet assay indicated that 2-MCPD did not induce DNA damage in both TM3 Leydig and TM4 Sertoli cells at tested concentrations. In the positive control (PC) cells, $100 \mu \mathrm{M} \mathrm{H}_{2} \mathrm{O}_{2}$ treatment for $1 \mathrm{~h}$ significantly increased the DNA tail intensity (\%) in both TM3 and TM4 cells (Figure 3).

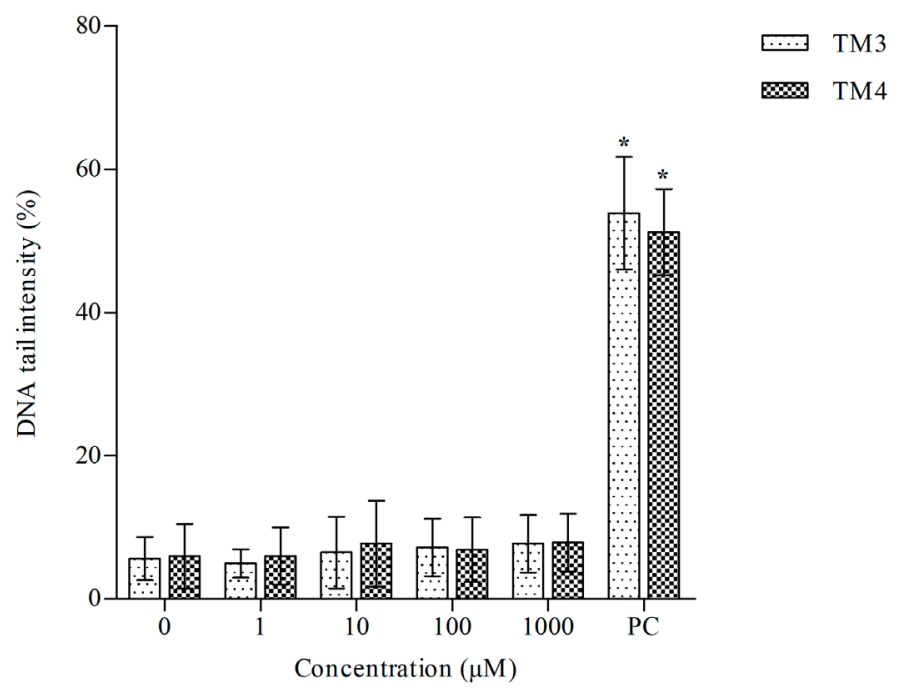

Figure 3. The level of the genotoxicity in TM3 Leydig and TM4 Sertoli cells treated by 2-MCPD (1-1000 $\mu \mathrm{M})$ and 100 $\mu \mathrm{M} \mathrm{H} \mathrm{O}_{2}$ for positive control (PC) cells. "DNA tail intensity $(\%) \pm$ SD" was used to evaluate the genotoxicity. *Statistically significant $(p<0.05)$.

\section{DISCUSSION}

Food safety has gained importance due to concerns about its effects on public health and economy. Chlorinated propanols such as 2-MCPD and 3-MCPD, and their esters are crucial compounds for the occurrence of foodborne diseases. Prior to entering systemic circulation, esterified forms of 2- and 3-MCPD are cleaved to free 2- and 3-MCPD (11,12). Daily mean dietary exposure in infants, adults and elderly range between 0.2 to $1.2 \mu \mathrm{g} / \mathrm{kg}$ body weight (bw) for 2-MCPD, and 0.2 to $2.6 \mu \mathrm{g} / \mathrm{kg}$ bw for 3-MCPD (1). Although 3-MCPD, an isomer of 2-MCPD, has been well studied, limited data are available for the toxicity of 2-MCPD (13).
3-MCPD has been classified under Category 2B (possibly carcinogenic to humans) according to the International Agency of Research for Cancer (IARC) $(6,14)$. Animal studies showed that testicles were the main target organs for 3-MCPD exposure, leading to male infertility and Leydig cell cancer. Other targets organs were reported as liver, kidneys and heart (4,15-17). 2-MCPD shows its toxic effects mostly on the striated muscle of the heart, liver, and kidneys (18). In adult male rats, the acute oral lethal dose $\left(\mathrm{LD}_{50}\right)$ of 2-MCPD and 3-MCPD were estimated as $50-60 \mathrm{mg} /$ $\mathrm{kg}$ bw (19) and $150 \mathrm{mg} / \mathrm{kg}$ bw, respectively (20), by using the 'Up and Down' procedure (OECD 425). The no-observed-adverse-effect level (NOAEL) for 2-MCPD was reported as $2 \mathrm{mg} / \mathrm{kg}$ bw per day in male rats (1).

In this study, the toxic effects of 2-MCPD on TM3 Leydig and TM4 Sertoli cells were identified in vitro. These mammalian male reproductive system cells are known as the target cells for 3-MCPD exposure. As 3-MCPD is similar to 2-MCPD in terms of molecular structure, we hypothesized that it may also have significant effects on reproductive system. Therefore, TM3 Leydig and TM4 Sertoli cells were exposed to varying concentrations of 2-MCPD (1, 10, 100, and 1000 $\mu \mathrm{M})$ for $24 \mathrm{~h}$ to investigate the effects on cell viability. The cytotoxicity data by MTT and NRU (Figure 1) assays revealed that 2-MCPD was not cytotoxic up to a level of $1000 \mu \mathrm{M}$.

Apoptotic/necrotic effect of the highest and lowest sub-toxic two concentrations of 2-MCPD were tested on TM3 Leydig and TM4 Sertoli cells. Data in Figure 2 confirms MTT results, as there was no significant difference between treatment and negative controls of each cell line. 2-MCPD did not induce apoptosis in TM3 Leydig and TM4 Sertoli cells. Similarly, Buhrke et al. (11) found that free forms of 2-MCPD and 3-MCPD did not induce cytotoxicity and caspase $3 / 7$ activity in Caco- 2 cells up to $1 \mathrm{mM}$. 
Data on the genotoxic effects of 2-MCPD are limited, and most of the available data consist of unpublished study reports. 2-MCPD was found to be mutagenic by Ames test without metabolic activation (unpublished report) (21). In V79 Chinese hamster lung cells, 2-MCPD was not induced at the hprt locus gene mutations up to extremely high concentrations (50 mM) with or without metabolic activation (unpublished report) (2). In Drosophila melanogaster, 2-MCPD showed genotoxic effect using the 'wing spot test' (22). Furthermore, no studies have been published on in vitro genotoxicity of 2-MCPD in mammalian cells. In this study, we demonstrated the genotoxic effects of 2-MCPD on TM3 Leydig and TM4 Sertoli cells in vitro. No significant difference was found in the DNA damage of TM3 Leydig and TM4 Sertoli cells treated by 2-MCPD compared to the control group $(p<0.05)$ (Figure 3). However, in the positive control group $(100 \mu \mathrm{M}$ H2O2 treatment for $1 \mathrm{~h}$ ), DNA tail intensity (\%) was approximately 5-fold of the $1 \mathrm{mM} 2$-MCPD exposed cells.

The inhibition of glycolysis has an important role in the development of 3-MCPD toxicity but, it is still unknown if 2-MCPD, the isomeric compound of 3-MCPD, has the same toxic mechanism of action (18). If their metabolism occurs through different oxidative steps, the metabolites of 2- and 3-MCPD should also be different which are responsible for the toxicity (23). As a consequence, further studies are needed to explain this difference.

Acknowledgement: This work was funded by Scientific and Technological Research Council of Turkey (TÜBİTAK) [Grant number: 117S863].

Conflict of interest: The authors declare that they have no conflict of interest.

\section{KAYNAKLAR}

1. EFSA (European Food Safety Authority). Chemicals in Food 2016. Overview of selected data collection. Available from: https://www.efsa.europa.eu/ sites/default/files/corporate_publications/ files/161215chemicalsinfoodreport.pdf Accessed December 10, 2019.

2. EFSA (European Food Safety Authority). Risks for human health related to the presence of 3- and 2-monochloropropanediol (MCPD), and their fatty acid esters, and glycidyl fatty acid esters in food. EFSA J. 2016;14(5):4426.

3. NTP (National Toxicology Program). Toxicology and carcinogenesis studies of glycidol (CAS No. 556-52-5) in genetically modified haplo insufficient p16Ink4a/p19Arf mice (gavage study). Natl Toxicol Program Genet Modif Model Rep. 2007;13:1-81.

4. Cho WS, Han BS, Lee H, Kim C, Nam KT, Park K, et al. Sub chronic toxicity study of 3-monochloropropane-1,2-diol administered by drinking water to B6C3F1 mice. Food Chem Toxicol. 2008;46:1666-73.

5. Cho WS, Han BS, Nam KT, Park K, Choi M, Kim SH, et al. Carcinogenicity study of 3-monochloropropane1,2-diol in Sprague-Dawley rats. Food Chem Toxicol. 2008;46:3172-7.

6. IARC (International Agency for Research on Cancer). Some chemicals present in industrial and consumer products, food and drinking-water. IARC Monographs. 2012;101:349-74.

7. Kuhlmann J. Determination of bound 2,3-epoxy-1propanol (glycidol) and bound monochloropropanediol (MCPD) in refined oils. Eur J Lipid Sci Technol. 2011;113:335-44.

8. Mosmann T. Rapid colorimetric assay for cellular growth and survival: application to proliferation and cytotoxicity assays. J Immunol Methods. 1983;65:55-63.

9. Repetto G, del Peso A, Zurita JL. Neutral red uptake assay for the estimation of cell viability/cytotoxicity. Nat Protoc. 2008;3(7):1125-31.

10. Singh NP, Mccoy MT, Tice RR, Schneder EL. A simple technique for quantitation of low levels of DNA damage in individual cells. Exp Cell Res. 1988;175(1):184-91.

11. Buhrke T, Frenzel F, Kuhlmann J, Lampen A. 2-Chloro1,3-propanediol (2-MCPD) and its fatty acid esters: cytotoxicity, metabolism, and transport by human intestinal Caco-2 cells. Arch Toxicol. 2015;89(12):224351. 
12. Kaze N, Watanabe Y, Sato H, Murota K, Kotaniguchi $\mathrm{M}$, Yamamoto $\mathrm{H}$, et al. Estimation of the intestinal absorption and metabolism behaviors of 2- and 3-Monochloropropanediol esters. Lipids. 2016;51(8):91322.

13. Schultrich K, Henderson CJ, Buhrke T, Braeuning A. Effects of 2-MCPD on oxidative stress in different organs of male mice. Food Chem Toxicol. 2020 May 29;142:111459.

14. Grosse Y, Baan R, Secretan-Lauby B, El Ghissassi F, Bouvard V, Benbrahim-Tallaa L, et al. Carcinogenicity of chemicals in industrial and consumer products, food contaminants and flavorings, and water chlorination by products. Lancet Oncol. 2011;12:328-9.

15. Sawada S, Oberemm A, Buhrke T, Meckert C, Rozycki C, Braeuning A, et al. Proteomic analysis of 3-MCPD and 3-MCPD dipalmitate toxicity in rat testis. Food Chem Toxicol. 2015;83:84-92.

16. Kirton KT, Ericsson RJ, Ray JA, Forbes AD. Male antifertility compounds: efficacy of U-5897 in primates (Macacamulatta). J Reproduction Fertil. 1970;21(2):2758.

17. Jones AR. Antifertility actions of alpha-chlorohydrin in the male. Aust J Biol Sci. 1983;36(4):333-50.
18. Schultrich K, Frenzel F, Oberemm A, Buhrke T, Braeuning A, Lampen A. Comparative proteomic analysis of 2-MCPD- and 3-MCPD-induced heart toxicity in the rat. Arch Toxicol. 2017;91(9):3145-55.

19. Marchesini M, Huggett A. The acute toxicity of 2-chloropropan 1,2 diol (up and down test) Unpublished report No. FS-RN920011 submitted to WHO by Nestec Ltd, Research \& Development, Switzerland. 1992.

20. Ericsson RJ, Baker VF. Male antifertility compounds: biological properties of U-5897 and U-15, 646. J Reprod Fertil. 1970;21:267-73.

21. Schilter B, Scholz G, Seefelder W. Fatty acid esters of chloropropanols and related compounds in food: Toxicological aspects. Eur J Lipid Sci Technol. 2011;113:309-13.

22. Frei H, Würgler, FE. The vicinal chloroalcohols 1,3-dichloro-2-propanol (DC2P), 3-chloro-1,2propanediol (3-CPD) and 2-chloro-1,3-propanediol (2CPD) are not genotoxic in vivo in the wing spot test of Drosophila melanogaster. Mutat Res. 1997;394:59-68.

23. Zhang Z, Yang P, Gao B, Huang G, Liu M, Yu LL. Synthesis of 2-Monochloropanol fatty acid esters and their acute oral toxicities in Swiss mice. J Agric Food Chem. 2019;6713:3789-95. 